\title{
The Implementation of Patient-Centered Collaborative Care Training Concept to Increase Inpatient Unit Nurse Performances of X Hospital
}

\author{
Yeyen Gustina Irawan* \\ *Correspondece Author: yeyengustina25@gmail.com \\ *Raden Mattaher Hospital, Jambi, Indonesia
}

\begin{tabular}{l}
\hline I N D E X I N G \\
\hline Keywords: \\
Implementation; \\
Patient Centered; \\
Collaborative Care;
\end{tabular}

\begin{abstract}
A B S T R A C T
The implementation of best Patient-Centered Collaborative Care training concept becomes one of the important aspects of providing health services in a hospital. The improvement of health services conducted bt the hospital is aimed to support healing and recovery with the full attention of patient comfort. This study used Mixed Method Research or a combination of quantitative and qualitative approaches os Sequential Explanatory, and qualitative data analysis in the second stage, to support the quantitative research finding which is done in the first stage. This study used One Group Pre - Test - Post - Test Design without Control, is a way of performing one pretest- before treatment (treatment/training) and afterward measuring again (post-test) without giving a control treatment. There are 96 respondents with one year of minimum work period in X Hospital. The respondent's observations are included gender, educational background, work period, status, children, residence and the workplace. The result of this study shows that the highest level of nurse's knowledge is influenced by the age, work experience, educational background, and motivation of self-development. Statistically, there are no signification differences, but from training appreciation, a nurse is unrealized that there is the influence of PCC implementation at the Surgical and Intern Ward Inpatient Unit X Hospital and supported by nurse's performances. Good knowledge of PCC concept proved to have an effect on PCC implementation inpatient Surgery and Interna Ward X Hospital supported by the improvement of nurse performance in inpatient room.
\end{abstract}

Kata Kunci:

Pelaksanaan;

Pasien berpusat;

Perawatan Kolaboratif;
Implementasi konsep pelatihan perawatan pada pasien menjadi salah satu aspek penting dalam memberikan pelayanan kesehatan dirumah sakit. Peningkatan pelayanan kesehatan yang dilakukan rumah sakit ditujukan untuk mendukung penyembuhan dan pemulihan dengan perhatian penuh pada kenyamanan pasien. Penelitian ini menggunakan Mixed Method Research atau kombinasi pendekatan kuantitatif dan kualitatif os Sequential Explanatory, dan analisis data kualitatif pada tahap kedua, untuk mendukung temuan penelitian kuantitatif yang dilakukan pada tahap pertama. Penelitian ini menggunakan One Group Pre-Test - Post-Test Design Without Control, adalah cara melakukan satu pretest sebelum perawatan (perawatan/pelatihan) dan sesudahnya mengukur lahi (post-test) tanpa dengan anda berikan perawatan kontrol. Ada 96 responden dengan masa kerja minimal satu tahun di X Hospital. Observasio responden termasuk jenis kelamin, latar belakang pendidikan, masa kerja, status, anak-anak, tempat tinggal dan tempat kerja. Hasil penelitin ini menunjukan bahwa tingkat pengetahuan perawat dipengaruhi oleh usia, pengalaman kerja, latar belakang pendidikan, dan motivasi pengembangan diri. Secara statistik, tidak ada perbedaan signifikasi, tetapi dari pelatihan preciation, perawatan tidak menyadari bahwa ada pengaruh pelaksanaan PCC di Unit Rawat Inp Bedah dan Penyakit Dalam di X Hospital dan didukung oleh perawat. Pengetahuan yang baik tentang konsep PCC terbukti berpengaruh terhadap implementasi PCC di Ruang Rawat Inap X Hospital didukung oleh peningkatan kinerja perawat diruang rawat inap.

(C) 2019 JMMR. All rights reserved

$\overline{\text { Article history: Received } 5}$ Feb 2017; Revised 15 Sept 2017; Accepted 25 Okt 2017

\section{INTRODUCTION}

Hospitals as a means of health services have an obligation to serve patients with complete facilities and fast and precise service. To archieve this the management of the hospital must be carried out properly. ${ }^{-}$The performance of nurses in applying a concept of health services can be felt by hospitals and also patients.

One of the concept of health services that is currently applied by hospitals in Indonesia that has been widely 
applied by developed countries is starch centered care (PCC) or one - centered services.

The PCC emphasizes that hospital managers need to look from the patients perspective or imaging themselves to be patient in orde to understand the patients needs and to be patient-focused hospitals. All hospital components, including clinicians, must apply the concept of PCC and the mindset that the patient is the only patient there to be truly focused, and not make decisions without involving the patient.

Patient Centered Care (PCC) is managing patients by referring and treating individual patients including preferences / needs, values, and ensuring that all clinical decision - making has taken into account all the values the patient wants. $\stackrel{2}{ }$

A single and integrated treatment plan identifying the measurable developments expected by each discipline is better than the separate treatment plan prepared by each practitioner. The patient care plan must reflect the specific treatment goals for each individual, objective and realistic so that later reassessment and revision of the plan can be carried out. To achieve these things must meet the following elements: Care of the patient is planned by doctors, nurses and other health professionals who are responsible within 24 hours after the patient enters as an inpatient, planned care is unique to each patients and based on the patient's initial assessment data, planned care is documented in the medical record in the form of measurable developments (targets), anticipated (revised) developments (targets) revised (if needed) based on patient reassessment by health care practitioners, care planned for each the patient is reviewed and verified by a doctor who is responsible for the notation in the progress notes, planned care is available. ${ }^{-}$

Patient safety (patient sfety from PCC) is a system whereby the hospital keeps the patients cre safer, prevents injuries caused by errors resulting from an action or not talking action that should be taken. The system includes risk recognition, identification and management of isssues related to patient risk, incident learning ability, follow-up and implementation of solutions to minimize risk. . $^{-}$

According to the Australian Commission on Safety and Quality in Health Care (ACSQHC) patient centered care is an innovative approach to planning, giving and evaluating health services based on mutually beneficial partnerships between health care providers, patients and families. Patient centered care is applied to patients of all age groups and can be practiced in every form of health. ${ }^{4}$
Application of PCC through the Hospital Accreditation Standard Version 2012: 1) Respect the patients values, choices and needs. 2) Participation of family and friends in the service process. 3) Information, Communication, Education 4) Continuing care to meet patient needs and smooth transition. 5) Acces to services. 6) Integration and Coordination 7) Physical comfort - Pain management 8) Emotional support and decreased anxiety, including in patients who will die Performance as a result of work functions / activities of a person or group in an organization that is influenced by various factors to archieve organixationl goals within a certain period of time..$^{5}$ Performance is the result of work quality and quantity archieved by an employee in performing their duties in accordance with the responsibilities given to him.

The standard of nursing practice has been described by PPNI (National Nurses Association of Indonesia, 2000) which refers to the stages of nursing process which includes: $:-5$ Nursing Assessment, the nursing collects data on the clients health status in a systematic, thorough, accurate, concise and sustainable manner. Nursing Diagnosis, the nursing analyzes the assessment data to formulate a nursing diagnosis. Nursing Planning, the nurse creates a nursing action plan to address the problem and improve the clients health. Implementation, the nurse implements the action identified in the nursing care plan. Nursing Evaluation, the nurse evaluates the clients progress toward nursing acting in achieving objectives and revising the baseline and planning data. Nurses are required to have knowledge and skills in various fields. Knowledge is the result of human sensation or the result of knowing someone about an object through the five senses it has such as vision, hearing, feeling. ${ }^{?}$

In all countries, staff nurses and the quality of the hospital work environment (managerial support for care, good doctor-nurse relationships, nurse participation in decision making, and organizational priorities on service quality) are significantly associated with patient satisfaction, quality and safety of care, and the results of labor nurses. More specifically, hospitals with good working environments and nursing staff have improved outcomes for patients and nurses alike.

According to the background and theories that have been described, the hypothesis of this study is: There are differences in Performances of Nurses before and after getting Patient Centered Care training. 


\section{RESEARCH METHOD}

This research plan is planned using Mixed Method Research, Mixed Method is a study that combines or combines qualitative and quantitative research approaches. By using Sequential Explanatory the combination research method is characterized by data collection and quantitative data analysis in the first stage, and qualitative data analysis in the second phase, to strengthen the results of quantitative research conducted in the first stage. In this study with One Group Pre-Test - Post-test Design without Control, is a way of performing one pre-test before treatment (training) and afterwards measuring again (post-test) without giving control treatment. This research will be carried out to nurses who work in the Internal Wark and Surgery Wark of Raden Mattaher Provinsi Jambi who have attended Patient Centered Care concept training. In obtaining the data needed to complete the process of this study, the authors conducted a series that originated from: Questionnaire, Documentation, and Interview.

\section{RESULT AND DISCUSSION}

Health workers invite patients and their families to make policies, plan and develop programs, implement and evaluate programs that will be obtained by patients. $\frac{10}{}$ One design model of patient centered care is a planetree model that has a concept $: \underline{11}$

a) Patients have the right to open and communicate honestly in their care and warmth of their environment.

b) Patients, families and professional staff have a vital role in the team.

c) Patients are not units that are isolated but members of family, community and culture.

d) Patients are individuals with rights, responsibilities and choices about lifestyle.

e) A supportive, friendly and caring environment is an important component that provides high quality health.

f) The physical environment is very important for the healing process and must be designed to promote healing and learning, and patients and families participate in care.

Based on the above table can be seen from the post-test the level of nurses knowledge about PCC after getting training is as much as $95.8 \%$ nurses understand well the definition of PCC, it has increased by $7.3 \%$ of pre-test. For the purposes of PCC, nurses who understand pcc increased $34.4 \%$ to $81.2 \%$. Similarly, the PCC component, from pretest results only $5.2 \%$ of nurses who know about PCC components, after training has increased as much as $77.1 \%$ nurses to understand about the coordination and integrity of care, physical comfort, access to services, emotional support, care sustainable. For the 4 core concepts of PCC the nurse knows a $9.4 \%$ increase.

\section{Table 1. Respondent characteristics}

\begin{tabular}{|c|c|c|c|}
\hline Category & Amount & Percentage & value \\
\hline $\begin{array}{l}\text { The definition of } \\
\text { PCC }\end{array}$ & 85 & 88.5 & Good \\
\hline PCC purpose & 45 & 46.8 & Poor \\
\hline PCC Conponents & 5 & 5.2 & $\begin{array}{l}\text { Very } \\
\text { Poor }\end{array}$ \\
\hline 4 core concepts & 78 & 81.2 & Good \\
\hline PCC's new focus & 77 & 80.2 & Good \\
\hline $\begin{array}{l}\text { The meaning of } \\
\text { patients in PCC }\end{array}$ & 49 & 51 & Average \\
\hline $\begin{array}{l}\text { The nurse's } \\
\text { responsibilitty to } \\
\text { the patient in } \\
\text { PCC }\end{array}$ & 56 & 58.3 & Average \\
\hline $\begin{array}{l}\text { Development } \\
\text { and application } \\
\text { of model of care }\end{array}$ & 46 & 47.9 & Poor \\
\hline $\begin{array}{l}\text { The center of } \\
\text { attention to the } \\
\text { patient }\end{array}$ & 76 & 79.2 & Good \\
\hline $\begin{array}{l}\text { Attitude of } \\
\text { health personel }\end{array}$ & 69 & 71.8 & Average \\
\hline
\end{tabular}

Prior to the training, many nurses were aware of the new PCC focus, at the time after the training the nurses were aware that the new PCC focus would increase by $6.3 \%$. Nurses are very good at understanding the meaning of patients according to the PCC can be seen an increase of $28.2 \%$ nurses who understand the patient is someone who gets the service although not in accordance with medical needs. Providing a process that supports the patient and family's right during service is the responsibility of the nurse to the patient in the concept of PCC understood both by the nurses, it can be seen an increase of $13.6 \%$ of people. The nurse's understanding of the development and application of "Model of Care" became one of the greatest increases. There were $32.3 \%$ of nurses knowing this was one of the PCC goals. For the center of attention in patients from only $79.2 \%$ of nurses who understood, it now becomes $84.4 \%$ of nurses. The increase in nurses who understand the importance of attention to patients is supported by the attitude of health workers in serving the patients also increases to $81.2 \%$ nurses understand how to respect patient privacy, listening, caring and respecting patient choice. 
In reseacrh Dwiyanto the title of Relationship between the Patient Centered Care Concept in Reducing Malpractice Events in the South Tangerang Regional Hospital in 2007 and result The incidence of malpractice in the South
Tangerang Regional Hospital decreased by $62 \%$ since the application of the concept of patient centered care in the South Tangerang Regional Public Hospital..$^{12}$

Table. 2 Average Nursing Knowledge Level of PCC After Training

\begin{tabular}{|c|c|c|c|c|c|}
\hline \multirow{2}{*}{ No. } & \multirow{2}{*}{ Category } & \multicolumn{2}{|c|}{$\mathbf{f}(\mathbf{n})$} & \multicolumn{2}{|c|}{$\%$} \\
\hline & & Good & Poor & Good & Poor \\
\hline 1 & Family and patient response to nursing services with the PCC concept & 81 & 15 & 84.38 & 15.62 \\
\hline 2 & Nurse Involvement with Family of Patient and Patient & 58 & 38 & 60.42 & 39.58 \\
\hline 3 & The concept of PCC and the strategic vision of the nurses & 75 & 21 & 78.13 & 21.87 \\
\hline 4 & $\begin{array}{l}\text { Application of the concept of PCC is supported by adequate technology } \\
\text { and facilities }\end{array}$ & 71 & 25 & 73.96 & 26.04 \\
\hline 5 & $\begin{array}{l}\text { Conducive Work Environment Conditions in the Application of the PCC } \\
\text { Concept }\end{array}$ & 77 & 19 & 80.2 & 19.8 \\
\hline 6 & $\begin{array}{l}\text { The application of the PCC concept is supported by other healthcare } \\
\text { professionals }\end{array}$ & 78 & 18 & 81.25 & 18.75 \\
\hline 7 & $\begin{array}{l}\text { The physical environment conditions are adequate in applying the concept } \\
\text { of PCC }\end{array}$ & 88 & 8 & 91.67 & 8.33 \\
\hline 8 & $\begin{array}{l}\text { The success rate of treatment in PCC application is influenced by the level } \\
\text { of education, occupation and social class }\end{array}$ & 78 & 18 & 81.25 & 18.75 \\
\hline 9 & Nurses participate in motivating patients & 93 & 3 & 96.88 & 3.12 \\
\hline 10 & Application of the PCC concept affects the patient's satisfaction level & 90 & 6 & 93.75 & 6.25 \\
\hline 11 & Information on health services provided & 84 & 12 & 87.5 & 12.5 \\
\hline 12 & Nurses maintain transparency of patient information & 85 & 11 & 88.54 & 11.46 \\
\hline 13 & Quality of care with the concept of PCC & 91 & 5 & 94.8 & 5.2 \\
\hline 14 & Services by Hospitals In accordance with the needs of patients & 85 & 11 & 88.54 & 11.46 \\
\hline 15 & Coordination and Integration of Nursing Care & 92 & 4 & 95.84 & 4.16 \\
\hline
\end{tabular}

Based on the above table it can be seen that $83.3 \%$ of nurses at Inpatient Ward Area Internal and Surgery Ward RSUD Raden Mattaher Jambi assess coordination and integration between doctors and nurses or among fellow nurses given to patients running well.

\section{Data Analysis Based on Nursing Performance Improvement Questionnaire on Nurse Inpatient Ward Surgery and Interna Ward}

To analyze the improvement of nurse's performance after getting the PCC concept training, the researcher will explain about nurse work variable. The variables used in the assessment of nurse performance improvement in the application of the concept of PCC is related to job satisfaction, motivation, work environment, and leadership. Here is the results of the nurse's performance assessment by the researcher:

Based on the above table it can be seen that as many as $95.8 \%$ of the nurses are aware to provide the best service for patients. but this is apparently only adequately supported by hospital management, the amount of income is also felt is still sufficient or fitting because there is still a lack of tools to measure the performance of PCC, as well as hospital policy in the provision of scholarships or training in nursing education.

Table.3 Motivation

\begin{tabular}{|c|c|c|c|c|}
\hline No. & Attribute Measurement & f (n) & $\%$ & Result \\
\hline 1 & Increased self-awareness from nurses to provide the best service & 92 & 95.8 & Good \\
\hline 2 & There is support and attention from the hospital management in performing the task & 81 & 84.3 & Good \\
\hline 4 & Hospital wisdom in the provision of scholarships or training in nursing education & 61 & 63.5 & Average \\
\hline
\end{tabular}


Table.4 Work Environment

\begin{tabular}{|c|c|c|c|c|}
\hline No. & Attribute Measurement & f (n) & $\%$ & Result \\
\hline 1 & Gender influence in dealing with patients & 76 & 79.2 & Good \\
\hline 2 & $\begin{array}{l}\text { The existence of clear standards and policies in performing the } \\
\text { task }\end{array}$ & 67 & 69.8 & Average \\
\hline 3 & The role of nursing assistant is very helpful for nursing work & 62 & 64.6 & Average \\
\hline 4 & $\begin{array}{l}\text { The hospital hours specified by the hospital are satisfactory for } \\
\text { the nurse }\end{array}$ & 58 & 60.4 & Average \\
\hline 5 & $\begin{array}{l}\text { There was no significant difference in status between the head } \\
\text { nurses and nurses in hospital environments }\end{array}$ & 77 & 80.2 & Good \\
\hline 6 & Doctors participate in helping to maximize services & 79 & 82.3 & Good \\
\hline 7 & High levels of patient dependence in the room & 82 & 85.4 & Good \\
\hline
\end{tabular}

Based on the above table can be seen the highest rating of $85.4 \%$ is in the high level of dependence patients in the room. $82.3 \%$ of GPs participate in helping to maximize treatment. There is also no significant difference in the status of head nurses and nurses in the hospital environment so that this can reduce the pressure in work can be seen as much as $80.2 \%$. It's just that the hours determined by the hospital are less suitable with the nurses. The existence of clear standards and policies in performing the duties and roles of nursing assistants in assisting nursing work is quite satisfactory. As for the high level of dependence of patients in the room considered still optimal enough for the nurses in helping the patient's health needs.

\section{Table.5 Leadership}

\begin{tabular}{clccc}
\hline No. & \multicolumn{1}{c}{ Attribute Measurement } & f (n) & Result & Good \\
\hline 1 & The leadership run in the nursing organization is satisfactory & 85 & 88.5 & 94.8 \\
2 & The head of the room is optimal in carrying out his duties & 91 & 94 & 97.9 \\
3 & Competent team leader performance & 87 & 90.6 & Good \\
4 & Leader's direction will be the division of tasks according to & & Good \\
& the abilities and readiness of the nurse & &
\end{tabular}

Based on the table Leadership can be seen that the influence of leadership on the performance of nurses is very large, as illustrated by the table above $88.5 \%$ nurses are satisfied with the leadership, it is supported by $90.6 \%$ nurses who agree leadership direction will be appropriate division of tasks. 94.8 nurses assess the head of the room is optimal in the duty. And the team leader that 97.8 nurses judged highly competent. Method of Anova GLM which have absolute value 0.000 where application of PCC very influence to nurse performance. The relationship of knowledge level and application of PCC concept by nurse in improving nurse performance can be seen in table below: Based on the table using the calculation of $\mathrm{T}$. Test results pretest and postest assessment of a number of 0.000 this is an absolute point there is a significant influence between pretest and posttest.

Table.6 Relationship Level of Knowledge and Application of PCC Concept in Improving Nurse Performance Inpatient Ward Surgery and Interna Ward RSUD Jambi

\begin{tabular}{|c|c|c|c|c|c|c|c|}
\hline \multirow{3}{*}{ Nursing Knowledge } & \multicolumn{4}{|c|}{ Application } & \multirow{2}{*}{\multicolumn{2}{|c|}{ Total }} & \multirow{3}{*}{$\mathbf{p}$} \\
\hline & \multicolumn{2}{|c|}{ Good } & \multicolumn{2}{|c|}{ Poor } & & & \\
\hline & f & $\%$ & f & $\%$ & f & $\%$ & \\
\hline Good & 58 & 60.41 & 18 & 18.75 & 76 & 79.2 & \\
\hline Poor & 11 & 11.46 & 9 & 9.4 & 20 & 20.8 & 0.989 \\
\hline Total & 69 & 71.87 & 27 & 28.13 & 96 & 100 & \\
\hline
\end{tabular}


Table shows that the relationship between the level of knowledge with the application of the concept of PCC in improving the performance of nurses is dominated by the good level of nurses knowledge of surgical wards and internal wards of the concept of PCC supported by the application of the concept of PCC by nurses in providing health services that is equal to $76(79.2 \%)$.

The result of research indicate that there is correlation of knowledge level with applying concept of PCC in

Table.7 Data Analysis Based on Interview Results improving nurse performance with value $\rho$ value equal to 0,012 and value $\rho<0,05$

\section{Data Analysis Based on Interview Results}

This activity is conducted by researchers in a structured manner using interview guidelines and organized into verbatim transcripts. The following is the interview theme which the author concisely based on PCC concept theory of PCC implementation section through the standard of Hospital Accreditation Version 2012:

\begin{tabular}{|c|c|c|}
\hline No & Category & Value \\
\hline 1 & $\begin{array}{l}\text { Respect the patient's values, choices, and } \\
\text { needs }\end{array}$ & $\begin{array}{l}\text { Respect the personal values and beliefs of the patient } \\
\text { Provide a process that supports the patient's and family's right in service }\end{array}$ \\
\hline 2 & $\begin{array}{l}\text { Participation of family and friends in service } \\
\text { process }\end{array}$ & Support family and friends to participate in the service process \\
\hline 3 & Information, Communication Education & $\begin{array}{l}\text { Education to support patient and family participation in decision making } \\
\text { Inform patients and families about care and service }\end{array}$ \\
\hline 4 & Ongoing care & $\begin{array}{l}\text { Identify patient needs } \\
\text { Responding to patient and family requests }\end{array}$ \\
\hline 5 & Access to services & $\begin{array}{l}\text { Provides information on an easy way to access the nearest health service } \\
\text { Describe special services that the patient can access }\end{array}$ \\
\hline 6 & Integration and Coordination & $\begin{array}{l}\text { Responsible for patient care } \\
\text { Design and implement processes to provide care services }\end{array}$ \\
\hline 7 & Physical Comfort & $\begin{array}{l}\text { Assist patients in daily activities } \\
\text { Maintain the hospital environment }\end{array}$ \\
\hline 8 & $\begin{array}{l}\text { Emotional Support and Anxiety Reduction, } \\
\text { including in the patient's death }\end{array}$ & Re-assessed according to their individual needs \\
\hline
\end{tabular}

According to Nitisemito (2000), states that companies should be able to reflect the conditions of the work environment that can support employee performance and cooperation between levels of superiors, subordinates and have the same position status in the company. Conditions that should be created are a family atmosphere, good communication, and control self. So it is expected that the Raden Mattaher Jambi Hospital will pay more attention to the good work environment. ${ }^{\underline{13}}$

\section{CONCLUSION}

Hospitals as a means of health services have an obligation to serve patients with complete facilities and fast and precise service. To archieve this the management of the hospital must be carried out properly. The performance of nurses in applying a concept of health services can be felt by hospitals and also patients. One of the concept of health services that is currently applied by hospitals in Indonesia that has been widely applied by developed countries is starch centered care (PCC) or one - centered services.
The PCC emphasizes that hospital managers need to look from the patients perspective or imaging themselves to be patient in orde to understand the patients needs and to be patient-focused hospitals. All hospital components, including clinicians, must apply the concept of PCC and the mindset that the patient is the only patient there to be truly focused, and not make decisions without involving the patient.

\section{REFERENCE}

1. Rhesavani, P. (2013) Evaluasi Sistem informasi Rekam Medis di RSU PKU Muhammadiyah Bantul Berdasarkan Pendekatan Kemudahan dan Kemanfaatan. Tugas Akhir (Tidak dipublikasikan). Yogyakarta: Program Diploma III Rekam Medis Sekolah Vokasi Universitas Gadjah Mada.

2. Frampton, S, et all. Patient Centered Care Improvement Guide. Inc. And Piker Institute. 2008

3. Depkes RI. 2008. Upaya Peningkatan Mutu Pelayanan Rumah Sakit. (konsep dasar dan prinsip). Jakarta: Depkes RI 
4. Lumenta, A. Nico. 2012. Patient Centered Care Sebagai "Trend Global" dalam Pelayanan Pasien. Workshop Keselamatan Pasien dan Manajemen Resiko Klinis. Ketua Komite Keselaatan Pasien Rumah Sakit. PERSI

5. Pabundu, Tika, 2006, Budaya Organisasi dan Peningkatan Kinerja Perusahaan, Jakarta: Cetakan Pertama, PT Bumi Aksara.

6. Persatuan Perawat Nasional Indonesia (PPNI), Perawat Indonesia. http://www.innappni.or.id/index.php/pendidikan-keperawatan diakses pada 17/04/2017 Jam 16.13 WIB

7. Soekidjo, Notoatmodjo. Metode Penelitian Kesehatan. (Jakarta: Rineka Cipta, 2005)

8. Frelitaa, G., Situmorang, T.J., \& Silitonga. D.S. 2011. Joint Commision International Accreditation Standards for Hospitals, 4 th edd. Oakbrook Terrace, Illinois 60181 U.S.A

9. Linda, H. Aiken, et all, 2012. BMJ 2012; doi:http://doi.org/10.1136/bmj.e1717 (Published 20 March 2012)

10. Kusumaningrum, Arie. 2009. Aplikasi dan Strategi Konsep Patient Centered Care Pada Hospitalisasi Anak Pra Sekolah. Fakultas Kedokteran Sriwijaya

11. Dewi, Dyah. 2011. Desain Fisik untuk Menciptakan Patient Centered Care. Evidence Based Design.

12. Dwiyanto, A. 2007. Penerapan Hospital by Laws Dalam Meningkatkan Patient Safety di Rumah Sakit. (Thesis). Semarang: Program Pascasarjana UNIKA Soegijapranata.

13. Alex S. Nitisemito 2000. Manajemen Personalia: Manajemen Sumber Daya Manusia, Ed. 3, Ghalia Indonesia, Jakarta. 